medRxiv preprint doi: https://doi.org/10.1101/2021.10.07.21264647; this version posted October 7, 2021. The copyright holder for this preprint (which was not certified by peer review) is the author/funder, who has granted medRxiv a license to display the preprint in perpetuity.

It is made available under a CC-BY 4.0 International license.

\title{
Cellular composition of human early and advanced coronary atherosclerotic lesions
}

Diana Sharysh ${ }^{1}$, Anton V. Markov ${ }^{1}$, Evgeniya S. Grigoryeva ${ }^{3}$, Olga E. Savelieva ${ }^{3}$, Aleksei A. Sleptcov ${ }^{1}$, Aleksei A. Zarubin ${ }^{1}$, Maria S. Nazarenko ${ }^{1,2}$

${ }^{1}$ Research Institute of Medical Genetics, Tomsk National Research Medical Center, Tomsk, Russia

${ }^{2}$ Siberian State Medical University, Tomsk, Russia

${ }^{3}$ Cancer Research Institute, Tomsk National Research Medical Center, Tomsk, Russia

Corresponding author: Maria Nazarenko, Ushayka Embankment 10, Tomsk, 634050, Russia; Email maria-nazarenko@medgenetics.ru; phone +7 (3822) 51-72-72

Keywords: atherosclerosis, flow cytometry, macrophage, vascular smooth muscle cell phenotype, endothelial cell

\begin{abstract}
Objective: Here, we identify and quantify leukocytes, macrophages, endothelial cells (ECs), and vascular smooth muscle cells (VSMCs) with contractile and macrophage-like phenotypes by flow cytometry to compare human early and advanced coronary atherosclerotic plaques.
\end{abstract}

Approach and Results: Sixteen coronary atherosclerotic lesions of 6 patients ( 3 women, 3 men, age $82 \pm 9$ years), including one case of restenosis after coronary stenting, were collected at autopsy. The cause of death of all patients was acute myocardial infarction. The lesions were categorized into early (EALs, $n=5$ ) and advanced (AALs, $n=11$ )

atherosclerotic stages. We analyzed a cell suspension stained with antibodies against CD45, CD68, CD31, and $\alpha$ SMA (ACTA2). We noted a decrease in the number of CD45+ cells and an increase in the $\mathrm{CD} 45^{+} \mathrm{CD} 68^{+}$subpopulation of leukocytes from EALs to AALs. Numbers of $\mathrm{CD}_{45}{ }^{-} \alpha \mathrm{SMA}{ }^{+} \mathrm{CD} 68^{+}$cells positively correlated with the $\mathrm{CD} 45^{+} \mathrm{CD} 68^{+}$macrophage number $(\mathrm{r}$ $=0.81 ; \rho=0.64 ; p<0.05)$ and the histological type of an atherosclerotic lesion $(r=0.81 ; \rho=$ $0.87 ; p<0.05)$. As an interesting case, we analyzed cellular composition of the stented coronary artery and revealed significantly greater numbers of macrophages, $\alpha \mathrm{SMA}^{+} \mathrm{CD} 68^{+}$ VSMCs, and ECs in comparison with nonstented plaques.

Conclusions: Human early and advanced coronary atherosclerotic lesions differ in their counts of leukocytes and leukocyte subpopulations. For the first time, $\alpha \mathrm{SMA}^{+} \mathrm{CD} 68^{+} \mathrm{VSMCs}$ were identified in early atherosclerotic stages of coronary arteries. Additionally, the restenotic coronary lesion contains mostly cells and is enriched in ECs, macrophages, and $\alpha \mathrm{SMA}^{+} \mathrm{CD} 68^{+}$VSMCs in particular.

\section{Abbreviations}

$\begin{array}{ll}\text { VSMCs } & \text { Vascular smooth muscle cells } \\ \text { ECs } & \text { Endothelial cells } \\ \text { DCs } & \text { Dendritic cells } \\ \text { SCRNA-seq } & \text { Single-cell RNA sequencing } \\ \text { EAL } & \text { Early atherosclerotic lesion } \\ \text { AAL } & \text { Advanced atherosclerotic lesion }\end{array}$


medRxiv preprint doi: https://doi.org/10.1101/2021.10.07.21264647; this version posted October 7, 2021. The copyright holder for this preprint (which was not certified by peer review) is the author/funder, who has granted medRxiv a license to display the preprint in perpetuity.

It is made available under a CC-BY 4.0 International license.

\section{INTRODUCTION}

Atherosclerosis is an age-associated chronic inflammatory disease that involves artery remodeling, significantly reduces quality of life, and leads to high rates of mortality and disability worldwide. ${ }^{1}$ Cellular composition of atherosclerotic arteries was initially investigated by histological techniques with various nonspecific staining methods (e.g., hematoxylin and eosin and Van Gieson's staining). These histological findings have been the basis for the histological classification of atherosclerotic stages incorporated into clinical practice. ${ }^{2}$

Nonetheless, the most important goal of atherosclerosis research is to predict adverse clinical outcomes of atherosclerotic disease. R. Virmani's group has suggested a concept of rupture-prone or vulnerable and stable atherosclerotic plaques according to plaque histological characteristics and cellular composition, respectively. ${ }^{3}$ They have stated that the inflammatory component plays a key role in the destabilization of an atherosclerotic plaque and in the development of acute cardiovascular events. On the other hand, vascular smooth muscle cells (VSMCs) form a fibrotic cap and play a protective part. ${ }^{4}$ Therefore, the varying cellular composition of the artery wall determines the clinical impact of atherosclerotic lesions.

Changes in the cellular composition during atherogenesis (from early stages to a complicated plaque) are still unclear. A healthy arterial wall consists of endothelial cells (ECs), VSMCs, fibroblasts, resident immune cells (e.g., dendritic cells [DCs], macrophages, and $T$ and B cells). ${ }^{5}$ Several studies have clarified cell diversity of the healthy arterial wall and identified multiple cellular subpopulations, e.g., pro- and antiatherogenic ECs, ${ }^{6}$ phenotypically modulated Sca $1^{+}$VSMCs, ${ }^{7}$ and various resident immune cell types. ${ }^{8}$

Atherosclerosis is associated with much higher cellular diversity in the artery wall owing to cell proliferation, phenotype switching, and the recruitment of immune cells in response to low-density lipoprotein cholesterol accumulation and oxidation. . $^{9,10}$ Immune cells (including macrophages) perform a pivotal function in the progression and destabilization of human atherosclerotic lesions. ${ }^{8}$ Plaque outcomes are determined by the balance of pro- and anti-inflammatory stimuli produced by these cells.

Recent studies uncovered a significant contribution of VSMCs to plaque formation, progression, and vulnerability. ${ }^{11}$ Nevertheless, due to phenotypic plasticity, VSMCs can play either an adverse or beneficial role in the atherosclerotic plaque. ${ }^{12}$ Different phenotypes of VSMCs (normally contractile, macrophage-like, osteogenic, or synthetic cells or fibromyocytes) are involved in atherosclerosis, ${ }^{11,13-15}$ but VSMC phenotypic switching is poorly studied in humans.

The current knowledge about the pathogenesis of atherosclerosis has been acquired mainly in studies on animal models or ex vivo human cell cultures. ${ }^{7,16-19}$ Atherosclerosis is a long-lasting disease, and therefore animal models reproduce the complex human biology insufficiently. ${ }^{20,21}$ There are fundamental differences between the human atherosclerotic disease and mouse models in T- and B-cell composition of atherosclerotic plaques. ${ }^{22}$ Murine atherosclerosis research involving single-cell RNA sequencing (scRNA-seq) technology has revealed high diversity of VSMC phenotypes, e.g., macrophage-like and stemlike. In contrast, scRNA-seq studies on human atherosclerotic plaques have not detected such diversity, except for synthetic and osteochondrogenic phenotypes. ${ }^{7,11,23,24}$

Quantitative and qualitative analyses of cells in the human atherosclerotic plaque to date have been based on a combination of flow cytometry or cytometry by time of flight (CyTOF) and scRNA-seq. ${ }^{11,23-27}$ These reports are cross-sectional (focusing on a single time point) and deal with either carotid or coronary arteries (mostly with advanced plaques). There are several flow-cytometric studies on human carotid, femoral, and aortic atherosclerotic plaques with an analysis of only a few or even a single cell type: VSMCs and immune cells, ${ }^{28}$ immune cells, ${ }^{26,29}$ T cells, ${ }^{30} \mathrm{DCs},{ }^{31}$ mast cells, ${ }^{32}$ and natural killer cells. ${ }^{33}$

There is only scarce information about the complex changes of ECs, leukocytes, macrophages, and VSMC phenotypes between early and advanced stages of coronary atherosclerotic lesions in humans. This work was aimed at identifying these cells in human coronary atherosclerosis and at assessing the differences in cell counts between early and 
medRxiv preprint doi: https://doi.org/10.1101/2021.10.07.21264647; this version posted October 7, 2021. The copyright holder for this preprint (which was not certified by peer review) is the author/funder, who has granted medRxiv a license to display the preprint in perpetuity.

It is made available under a CC-BY 4.0 International license.

advanced atherosclerotic lesions by flow cytometry. For cell staining, we used a set of markers whose combination allows to distinguish the following cell types: ECs $\left(\mathrm{CD}_{45}^{-} \alpha \mathrm{SMA}^{-} \mathrm{CD} 31^{+}\right)$, leukocytes $\left(\mathrm{CD} 45^{+}\right)$and separately macrophages $\left(\mathrm{CD} 45^{+} \mathrm{CD} 68^{+}\right)$and contractile $\left(\mathrm{CD}^{4} 5^{-} \alpha \mathrm{SMA}^{+} \mathrm{CD} 68^{-}\right)$and macrophage-like $\left(\mathrm{CD}^{-} 5^{-} \alpha \mathrm{SMA}^{+} \mathrm{CD} 68^{+}\right) \mathrm{VSMCs}^{-}$

\section{MATERIALS AND METHODS}

The data that support the findings of this study are available from the corresponding author upon reasonable request.

\section{Donor material}

Sixteen samples of the coronary artery were obtained from 6 donors ( 3 males, 3 females, age $82 \pm 9$ years [mean \pm SD]) during autopsy. All donors had a cardiovascular disease(s) in their medical history. In all cases, acute coronary syndrome (myocardial infarction) with cardiogenic shock was the cause of death (Table 1).

Table 1. Clinical characteristics of the donors of biological material

\begin{tabular}{|c|c|c|c|c|c|c|c|c|}
\hline \multirow[t]{2}{*}{ ID } & \multirow[t]{2}{*}{ Sex } & \multirow[t]{2}{*}{ Age } & \multirow[t]{2}{*}{ Main disease } & \multirow[t]{2}{*}{ Complications } & \multirow[t]{2}{*}{$\begin{array}{l}\text { Concomitant } \\
\text { disease }\end{array}$} & \multirow[t]{2}{*}{ Other diseases } & \multicolumn{2}{|c|}{$\begin{array}{l}\text { The histological type } \\
\text { of harvested artery } \\
\text { samples (AHA } \\
\text { classification) }\end{array}$} \\
\hline & & & & & & & $E A L$ & $\overline{A A L}$ \\
\hline 1 & $\mathrm{~F}$ & $\begin{array}{l}86- \\
90\end{array}$ & $\begin{array}{l}\text { CAD: Non-STEMI, } \\
\text { paroxysmal atrial } \\
\text { fibrillation, NYHA III, } \\
\text { obesity, } \\
\text { nephrosclerosis, } \\
\text { hypertension III }\end{array}$ & $\begin{array}{l}\text { Killip III. } \\
\text { Pulmonary } \\
\text { embolism }\end{array}$ & $\begin{array}{l}\text { Community- } \\
\text { acquired } \\
\text { pneumonia }\end{array}$ & $\begin{array}{l}\text { Chronic cholangitis, } \\
\text { cholecystitis }\end{array}$ & II & VII \\
\hline 2 & $F$ & $\begin{array}{l}86- \\
90\end{array}$ & $\begin{array}{l}\text { CAD: STEMI, atrial } \\
\text { fibrillation, NYHA III, } \\
\text { cardiac fibrosis, } \\
\text { hypertension III }\end{array}$ & $\begin{array}{l}\text { Killip IV. } \\
\text { Cardiogenic } \\
\text { shock, } \\
\text { pulmonary } \\
\text { embolism }\end{array}$ & $\begin{array}{l}\text { Hypertension III, } \\
\text { nephrosclerosis, } \\
\text { chronic kidney } \\
\text { disease }\end{array}$ & $\begin{array}{l}\text { Chronic anemia, } \\
\text { chronic } \\
\text { pyelonephritis, } \\
\text { kidney cysts }\end{array}$ & III & VII \\
\hline 3 & $\mathrm{M}$ & $\begin{array}{l}80- \\
85\end{array}$ & $\begin{array}{l}\text { CAD: STEMI, } \\
\text { postinfarction } \\
\text { cardiosclerosis, } \\
\text { paroxysmal atrial } \\
\text { fibrillation, NYHA 2a, } \\
\text { hypertension III }\end{array}$ & $\begin{array}{l}\text { Killip IV. } \\
\text { Cardiogenic } \\
\text { shock }\end{array}$ & $\begin{array}{l}\text { Cerebrovascular } \\
\text { accident }\end{array}$ & $\begin{array}{l}\text { Cholelithiasis, } \\
\text { cholecystectomy, } \\
\text { community-acquired } \\
\text { pneumonia }\end{array}$ & I & IV \\
\hline 4 & $\mathrm{M}$ & $\begin{array}{l}80- \\
85\end{array}$ & $\begin{array}{l}\text { CAD: STEMI, } \\
\text { cardiosclerosis, the } \\
\text { paroxysmal form of } \\
\text { atrial fibrillation, } \\
\text { ventricular extrasystole, } \\
\text { blockade of the right } \\
\text { bundle branch block, } \\
\text { NYHA III, hypertension } \\
\text { III, } \\
\text { Stent "Biomime" }\end{array}$ & $\begin{array}{l}\text { Cardiogenic } \\
\text { shock, brain } \\
\text { edema, } \\
\text { pulmonary } \\
\text { embolism }\end{array}$ & $\begin{array}{l}\text { Cerebrovascular } \\
\text { accident, chronic } \\
\text { obstructive } \\
\text { pulmonary } \\
\text { disease }\end{array}$ & Anemia, kidney cyst & $\mathrm{I}$ & $\mathrm{VI}$ \\
\hline 5 & $\mathrm{M}$ & $\begin{array}{l}66- \\
70\end{array}$ & $\begin{array}{l}\text { CAD: STEMI, } \\
\text { postinfarction } \\
\text { cardiosclerosis, NYHA } \\
\text { III }\end{array}$ & $\begin{array}{l}\text { Killip IV. } \\
\text { Cardiogenic } \\
\text { shock, } \\
\text { pulmonary } \\
\text { edema }\end{array}$ & $\begin{array}{l}\text { Chronic } \\
\text { obstructive } \\
\text { pulmonary } \\
\text { disease IV, } \\
\text { chronic } \\
\text { pulmonary heart }\end{array}$ & $\begin{array}{l}\text { Community-acquired } \\
\text { pneumonia, } \\
\text { hypertension III, } \\
\text { type } 2 \text { diabetes, } \\
\text { cholecystitis, cystic- } \\
\text { bullous } \\
\text { transformation, } \\
\text { nephropathy, } \\
\text { pyelonephritis }\end{array}$ & II & IV \\
\hline 6 & $\mathrm{~F}$ & $\begin{array}{l}90- \\
95\end{array}$ & $\begin{array}{l}\text { CAD: STEMI, } \\
\text { postinfarction } \\
\text { cardiosclerosis, } \\
\text { ventricular extrasystole, } \\
\text { blockade of the anterior } \\
\text { superior bundle branch }\end{array}$ & $\begin{array}{l}\text { Post- } \\
\text { infarction } \\
\text { cardiosclerosi } \\
\text { s, NYHA Ila } \\
\text { hydrothorax }\end{array}$ & $\begin{array}{l}\text { Thrombosis of } \\
\text { mesenteric } \\
\text { vessels, } \\
\text { community- } \\
\text { acquired } \\
\text { pneumonia }\end{array}$ & $\begin{array}{l}\text { Type } 2 \text { diabetes, } \\
\text { pseudomembranous } \\
\text { colitis, cholelithiasis, } \\
\text { chronic calculous } \\
\text { cholecystitis, } \\
\text { polyosteoarthrosis, } \\
\text { osteoporosis, } \\
\text { nephropathy }\end{array}$ & $\begin{array}{l}\text { Not } \\
\text { detected }\end{array}$ & VII \\
\hline
\end{tabular}

The study protocol was approved by the Local Biomedical Ethics Committee of the Research Institute of Medical Genetics, Tomsk National Research Medical Center (protocol 
medRxiv preprint doi: https://doi.org/10.1101/2021.10.07.21264647; this version posted October 7, 2021. The copyright holder for this preprint (which was not certified by peer review) is the author/funder, who has granted medRxiv a license to display the preprint in perpetuity.

It is made available under a CC-BY 4.0 International license .

No. 158). The study complied with the Declaration of Helsinki and was conducted in accordance with Russian laws and regulations and institutional policies.

\section{Examination of human coronary atherosclerotic lesions}

Left and right coronary arteries from all donors (total length $\sim 10-12 \mathrm{~cm}$ ) were examined with the naked eye and classified as either an early atherosclerotic lesion (EAL; from initial changes up to fatty streaks, without a lipid core) or an advanced atherosclerotic lesion (AAL; a plaque with a lipid core, calcinates, and thrombus). Every sample of the coronary artery was divided into 2 equal pieces: for histological examination and flowcytometric analysis. The interval between the time of death and sample processing was less than 6 hours.

The tissue samples for histological examination were fixed in $10 \%$ formalin, sliced on a microtome, stained with hematoxylin and eosin, and then evaluated by a histopathologist according to American Heart Association (AHA) criteria 2. Consistency between the visual EAL/AAL classification and the histological type of atherosclerosis is demonstrated in Table 1.

The remaining pieces of the artery samples were placed into DMEM (PanEco, cat. No. C410p) and quickly delivered (on ice) to the laboratory for further preparation. The artery samples were cleaned on ice from perivascular fat and soft tissue. The processed samples were placed in a cryopreservation medium (10\% dimethyl sulfoxide, $20 \%$ fetal bovine serum in DMEM) and cooled slowly down to $-80^{\circ} \mathrm{C}$ in a Mr. Frosty Freezing Container (Thermo Fisher Scientific).

\section{Disaggregation of human coronary atherosclerotic lesions}

Tissue samples were thawed quickly at $37^{\circ} \mathrm{C}$, weighed, washed with PBS, and finely minced in $1.5 \mathrm{~mL}$ tubes containing $0.5 \mathrm{~mL}$ of PBS supplemented with $20 \mathrm{mM}$ HEPES, pH 7.0-7.6. The crude suspension was incubated for 1 hour at $37^{\circ} \mathrm{C}$ with a digestion mix: 250 $\mathrm{U} / \mathrm{mL}$ collagenase type IV (PanEco, cat. No. ח011-4), $60 \mathrm{U} / \mathrm{mL}$ DNase type I (Prospecbio, cat. No. ENZ-417), $60 \mathrm{U} / \mathrm{mL}$ hyaluronidase I-S (Sigma-Aldrich, cat. No. H3506), and $100 \mu \mathrm{g}$ of $\mathrm{CaCl}_{2}$ in $2.5 \mathrm{~mL}$ of PBS with $20 \mathrm{mM} \mathrm{HEPES}, \mathrm{pH}$ 7.0-7.6 (Sigma-Aldrich, cat. No. H3375). Next, filtration through a $70 \mu \mathrm{m}$ BD Falcon ${ }^{\mathrm{TM}}$ Cell Strainer (Becton Dickinson, cat. No. 352350), centrifugation ( $300 \times g$ at $4^{\circ} \mathrm{C}$ for 15 minutes), and resuspension of the cell pellet in $2.5 \mathrm{~mL}$ of PBS were performed followed by the second digestion step $(200 \mathrm{U} / \mathrm{mL}$ collagenase type IV for 20 minutes). After the second filtration and centrifugation step, each cell pellet was resuspended in $1 \mathrm{~mL}$ of PBS supplemented with $5 \%$ of fetal bovine serum (Biosera, cat. No. FB-1001/500) (FACS buffer) for the blocking of Fc fragments. The numbers and viability of the cells in each suspension were estimated by trypan blue staining in a LUNA II cell counter (Logos Biosystems).

\section{Flow cytometry of cell suspensions}

We determined cell types by flow cytometry on a MoFlo XDP instrument (Beckman Coulter) equipped with $488 \mathrm{~nm}$ and $640 \mathrm{~nm}$ laser lines. The gating strategy used to identify cell types is outlined in Fig. 1 a.

The staining of surface and intracellular antigens was performed as follows: $1 \mathrm{~mL}$ of a cell suspension was centrifuged at $300 \times g$ for 15 minutes. The cell pellet was resuspended in $100 \mu \mathrm{L}$ of FACS buffer with subsequent addition of monoclonal antibodies against CD45 (antibody conjugated with allophycocyanin H7; Mouse IgG1, kappa, Clone 2D1) and against CD31 (antibody conjugated with phycoerythrin and cyanine 7; Mouse IgG1, kappa, Clone WM59 [RUO], Becton Dickinson, cat. No. 560274 and 563651, respectively) diluted at their optimal titer (please see the Major Resources Table in Supplemental Materials). The suspension was incubated in the dark for 20 minutes. 
medRxiv preprint doi: https://doi.org/10.1101/2021.10.07.21264647; this version posted October 7, 2021. The copyright holder for this preprint (which was not certified by peer review) is the author/funder, who has granted medRxiv a license to display the preprint in

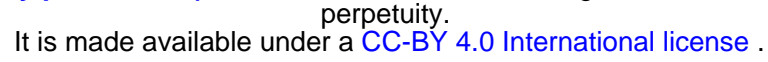

Next, the cells were permeabilized by means of BD Cytofix/Cytoperm Fixation and Permeabilization Solution (Becton Dickinson, cat. No. 554714) according to the manufacturer's protocol. Briefly, $1 \mathrm{~mL}$ of $1 \times$ BD Perm/Wash buffer was added to the cell suspension, and the mixture was centrifuged at $300 \times g$ for 10 minutes. The BD Fix/Perm solution was added to the cell pellet followed by vortexing and incubation of the mixture in the dark for 20 minutes at $4^{\circ} \mathrm{C}$. The cells were washed with BD Perm/Wash buffer as described above. The cell pellet was resuspended in $50 \mu \mathrm{L}$ of BD Perm/Wash buffer, then monoclonal antibodies against intracellular antigens $\alpha$ SMA (antibody conjugated with phycoerythrin; Monoclonal Mouse IgG2A Clone 1A4, R\&D Systems, cat. No. IC1420P) and CD68 (antibody conjugated with fluorescein isothiocyanate; Mouse BALB/c IgG2b kappa, Becton Dickinson, cat. No. 562117) were added at an optimal titer, and the mixture was incubated in darkness for 15 minutes at $4^{\circ} \mathrm{C}$. Finally, the cell suspension was washed with BD Perm/Wash buffer and resuspended in $500 \mu \mathrm{L}$ of the IsoFlow Sheath Fluid (Beckman Coulter).

The corresponding unstained samples served as a negative control. Compensation was performed using the VersaComp Antibody Capture Bead Kit (cat. No. B22804, Beckman Coulter). In preparation for the downstream data analysis, debris and dead cells were removed. Doublets were identified by means of a ratio of forward scatter signal area (FSC-A) to height (FSC-H) and excluded, followed by gating of cells on the basis of forward and side scatter characteristics.

To identify cellular subsets of interest in the cell suspension samples, a gating strategy based on marker expression patterns was implemented in Summit v5.2 (Beckman Coulter) and NovoExpress v1.4.1 (Agilent Technologies Inc.) software. CD45 ${ }^{+}$cells were designated as leukocytes, CD45 ${ }^{+} \mathrm{CD}_{68}{ }^{+}$cells as macrophages, $\mathrm{CD}^{-} 5^{-} \alpha \mathrm{SMA}^{-} \mathrm{CD} 31^{+}$cells as $\mathrm{ECs}$, and $\mathrm{CD}^{4}{ }^{-} \alpha \mathrm{SMA}^{+} \mathrm{CD}^{-} 8^{-}$and $\mathrm{CD}^{-}{ }^{-} \alpha \mathrm{SMA}^{+} \mathrm{CD} 68^{+}$cells were assumed to be contractile and macrophage-like VSMCs, respectively. All numbers of cells correspond to singlets.

To check the specificity of our cell sorting, we placed sorted cells on a slide and examined them by fluorescence microscopy (Fig. 1b). 
medRxiv preprint doi: $h$ ttps://doi.org/10.1101/2021.10.07.21264647; this version posted October 7, 2021. The copyright holder for this preprint (which was not certified by peer review) is the author/funder, who has granted medRxiv a license to display the preprint in

perpetuity.
It is made available under a CC-BY 4.0 International license .
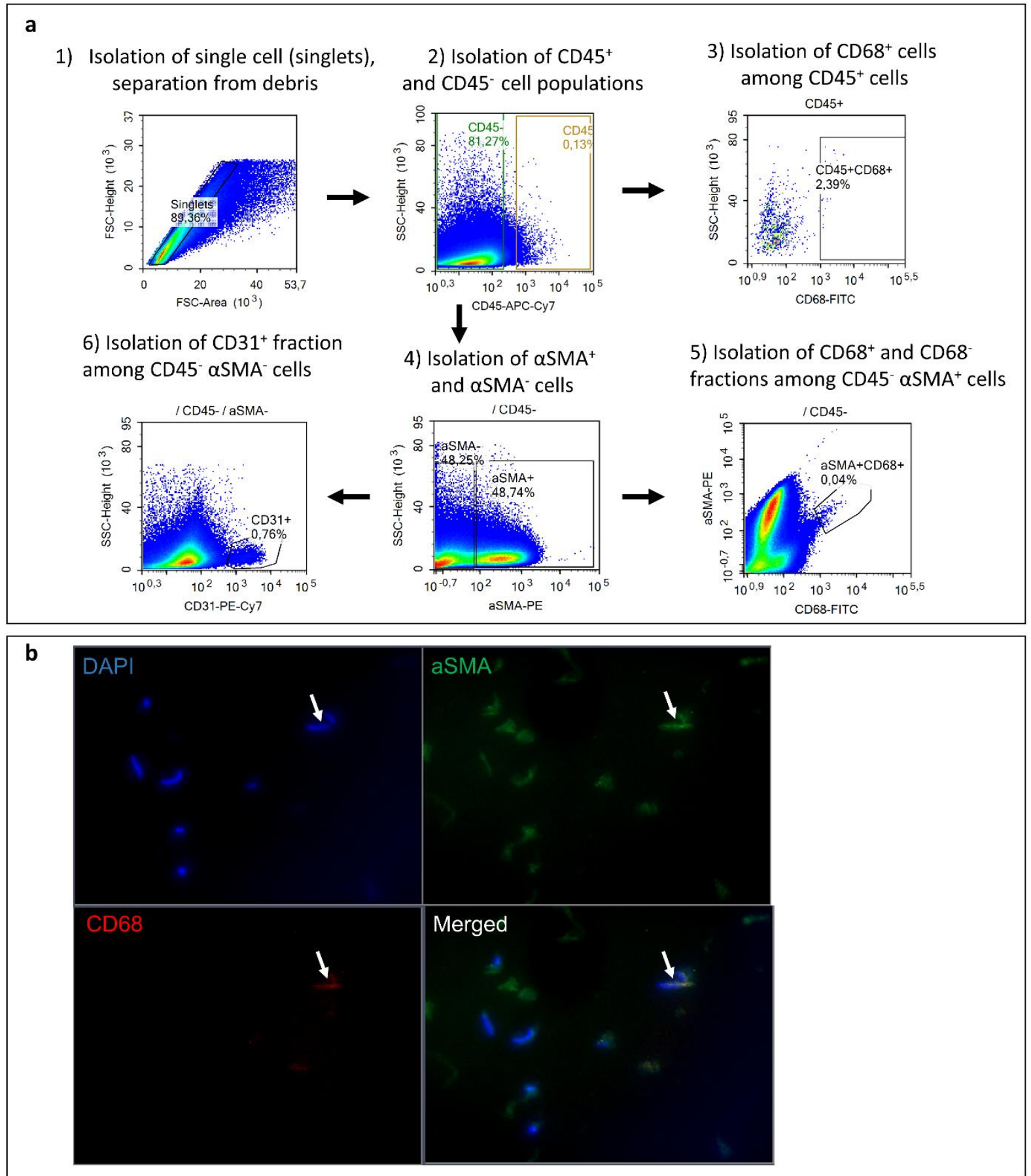

Figure 1. a. An outline of the flow-cytometric analysis. The main steps of the analysis include: (1) isolation of singlet cells from debris; (2) isolation CD45+ cells from singlets; (3) isolation of $\mathrm{CD}^{+} 8^{+}$cells from $\mathrm{CD} 45^{+}$cells; (4) isolation of $\alpha \mathrm{SMA}^{+}$and $\alpha \mathrm{SMA}^{-}$cells from CD45 cells; (5) isolation of $\mathrm{CD}^{-} 8^{+}$and $\mathrm{CD}^{-} 8^{-}$cells from $\alpha \mathrm{SMA}^{+}$cells; (6) isolation of CD31+ cells from $\alpha \mathrm{SMA}^{-}$cells. b. Fluorescence microscopy of sorted $\alpha \mathrm{SMA}^{+}$cells to validate the flow-cytometric strategy. 
medRxiv preprint doi: https://doi.org/10.1101/2021.10.07.21264647; this version posted October 7, 2021. The copyright holder for this preprint (which was not certified by peer review) is the author/funder, who has granted medRxiv a license to display the preprint in perpetuity.

It is made available under a CC-BY 4.0 International license.

\section{Statistical analysis}

We compared proportions of the identified cell types between EAL and AAL samples by the Mann-Whitney test. The sample of the stented artery was compared with nonstented samples via the one-sample Wilcoxon signed-rank test. Statistical analysis was performed in JASP (v0.11.1, JASP Team). Correlations were evaluated by Spearman's analysis and Pearson's linear correlation analysis. Statistical significance was defined as $p<0.05$. Variance in the analyzed groups is presented as either the mean \pm SD or median (Me) and first (Q1) and third (Q3) quartiles in the form of "Me (Q1; Q3)."

\section{RESULTS}

\section{The cell types identified in EALs and AALs}

The weights of EAL and AAL samples were $0.42 \pm 0.18$ and $0.64 \pm 0.35 \mathrm{~g}$, respectively. EAL samples contained 834000 (482000; 1186000) cells per $0.1 \mathrm{~g}$ of wet tissue, with $64(60 ; 68) \%$ viability in suspension after disaggregation. AALs consisted of $312000(52300 ; 470000)$ cells per $0.1 \mathrm{~g}$ with $55(49 ; 63) \%$ viability.

EALs contained CD45+ leukocytes at $15.7(11.9 ; 16.1) \%$ of all cells, while the proportion of $\mathrm{CD}^{2} 5^{+} \mathrm{CD} 68^{+}$macrophages was $0.39(0.28 ; 0.55) \%$ (Table 2). Resident cells in EALs were as follows: CD45 ${ }^{-} \alpha \mathrm{SMA}^{+}$VSMCs at $17.6(10 ; 41.5) \%$ and CD45-CD31 ${ }^{+}$ECs at $0.4(0.3 ; 1.4) \%$. Contractile VSMCs were abundant, $15.9(7.3 ; 39.7) \%$, in comparison with macrophage-like VSMCs, $1.9(0.8 ; 2.9) \%$.

In AALs, we found CD45+ leukocytes at $8.1(3.9 ; 8.6) \%$, which included CD45+CD68+ macrophages at $0.59(0.2 ; 0.66) \%$ (Table 2). All CD45 $\alpha{ }^{-} \mathrm{SMA}^{+}$VSMCs constituted 24 (10; $35.5) \%$ of all cells; $3.7(1 ; 9.1) \%$ of VSMCs had the macrophage-like phenotype $\left(\mathrm{CD}^{+} 8^{+}\right)$, and $15.7(7.2 ; 26.8) \%$ of VSMCs had the contractile (CD68 $\left.{ }^{-}\right)$phenotype. The proportion of ECs was $0.6(0.5 ; 2.8) \%$ among all cells.

\section{Changes of immune cells between the EAL and AAL stages}

We found a statistically significantly $(p=0.003$ ) greater relative number of CD45 leukocytes in EALs [15.7 (11.9; 16.1)\%] than in AALs [8.1 (3.9; 8.5)\%; Table 2 and Fig. 2a].

The proportion of macrophages $\left(\mathrm{CD} 45^{+} \mathrm{CD} 68^{+}\right)$among $\mathrm{CD} 45^{+}$leukocytes did not differ between the stages of atherosclerotic lesions and was $0.5(0.2 ; 0.6) \%$, but the proportion of macrophages among $\mathrm{CD}_{4} 5^{+}$leukocytes was significantly higher in AAL samples [6.7 (5.0; 7.8)\%] than in EAL samples [3.0 (1.9; 3.6)\%; $p=0.003$; Fig. 2b]. Additionally, CD45+ leukocyte content tended to negatively correlate with the histological type of atherosclerotic lesions (Pearson's linear correlation coefficient $r=-0.57, p=0.178$;

Spearman's correlation coefficient $\rho=-0.73, p=0.064$; Fig. $2 g$ ).

We also noticed a rank correlation of the number of $\mathrm{CD}^{2} 8^{+}$macrophages with the numbers of ECs $(\rho=0.58, p=0.04)$, contractile VSMCs $(\rho=0.63, p=0.02)$, and macrophage-like VSMCs $(r=0.81, p<0.001 ; \rho=0.64, p=0.02$; Fig. $2 g)$.

Table 2. Proportions of cell types identified in early and advanced coronary atherosclerotic lesions

\begin{tabular}{|c|c|c|c|c|}
\hline \multirow[t]{2}{*}{ Cell type } & \multirow[t]{2}{*}{ Cell markers } & \multicolumn{2}{|c|}{ Cell proportion (\% of all cells) } & \multirow[t]{2}{*}{$p$} \\
\hline & & $\mathrm{EAL}(\mathrm{n}=5)$ & $\mathrm{AAL}(\mathrm{n}=11)$ & \\
\hline Leukocytes & $\mathrm{CD}^{2} 5^{+}$ & $15.7(11.9 ; 16.1)$ & $8.1(3.9 ; 8.6)$ & $0.003^{*}$ \\
\hline Macrophages & $\mathrm{CD}^{2} 5^{+} \mathrm{CD} 68^{+}$ & $0.39(0.28 ; 0.55)$ & $0.59(0.2 ; 0.66)$ & 0.604 \\
\hline VSMCs (common) & ${\mathrm{CD} 45^{-} \alpha \mathrm{SMA}^{+}}^{+}$ & $17.6(10 ; 41.5)$ & $24(10 ; 35.5)$ & 0.940 \\
\hline Contractile VSMCs & $\mathrm{CD}^{-}{ }^{-} \alpha \mathrm{SMA}^{+} \mathrm{CD}^{-} 8^{-}$ & $15.9(7.3 ; 39.7)$ & $15.7(7.2 ; 26.8)$ & 0.825 \\
\hline Macrophage-like VSMCs & $\mathrm{CD}^{2}{ }^{-} \alpha \mathrm{SMA}^{+} \mathrm{CD} 8^{+}$ & $1.9(0.8 ; 2.9)$ & $3.7(1 ; 9.1)$ & 0.414 \\
\hline ECs & $\mathrm{CD}^{2} 5^{-} \mathrm{CD} 31^{+}$ & $0.4(0.3 ; 1.4)$ & $0.6(0.5 ; 2.8)$ & 0.414 \\
\hline
\end{tabular}

$\mathrm{AAL}$, advanced atherosclerotic lesion; EAL, early atherosclerotic lesion; ECs: endothelial cells; VSMCs, vascular smooth muscle cells. 
medRxiv preprint doi: https://doi.org/10.1101/2021.10.07.21264647; this version posted October 7, 2021. The copyright holder for this preprint (which was not certified by peer review) is the author/funder, who has granted medRxiv a license to display the preprint in perpetuity.

It is made available under a CC-BY 4.0 International license.


Figure 2. Relative numbers of identified leukocytes in coronary atherosclerotic lesions. a. Proportion of all CD45+ leukocytes among singlets. b. Proportion of $\mathrm{CD}^{+} 8^{+}$macrophages among CD45+ leukocytes. EAL, early atherosclerotic lesion; AAL, advanced atherosclerotic lesion. c-f. Proportions of nonimmune cell types identified in early and advanced coronary atherosclerotic lesions. c. Endothelial cells. d. Vascular smooth muscle cells (common type). e. Vascular smooth muscle cells with the contractile phenotype. f. Vascular smooth muscle cells with the macrophage-like phenotype. g. Heatmaps of correlation between numbers of various cell types and the histological type of atherosclerotic lesions. Top right: Pearson's linear correlation coefficient. Left bottom: Spearman's correlation coefficient. An asterisk denotes coefficients with a statistically significant difference from zero: ${ }^{*} p<0.05$. $\mathbf{h}$. Correlation between the number of macrophage-like VSMCs and the histological type of atherosclerotic lesions (according to AHA classification). i. Proportions of cell types identified in different coronary atherosclerotic lesions from the same patient (several patients). Myelo: $\mathrm{CD}^{+} 8^{+}$macrophages, CD45+CD68-: non-CD68 leukocytes, contractile VSMCs: $\alpha \mathrm{SMA}^{+} \mathrm{CD}^{+} 8^{-}$ contractile vascular smooth muscle cells, macrophage-like VSMCs: $\alpha S M A^{+} C^{2} 68^{+}$ macrophage-like vascular smooth muscle cells, ECs: CD $31^{+}$endothelial cells; EAL: early 
medRxiv preprint doi: https://doi.org/10.1101/2021.10.07.21264647; this version posted October 7, 2021. The copyright holder for this preprint (which was not certified by peer review) is the author/funder, who has granted medRxiv a license to display the preprint in

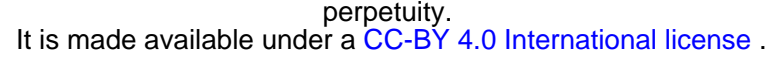

atherosclerotic lesion, AAL: advanced atherosclerotic lesion; AAL-(N): ID number of an advanced atherosclerotic plaque, among several from the same patient (where possible). $\mathbf{j}$, k. Histological examination of a coronary sirolimus-eluting stent that had been implanted 10 months before the autopsy. j. Neoatherosclerotic lesion. k. Adjacent tissue. NC, necrotic core; HR, hemorrhage; C, calcification; CT, cap thinning. Hematoxylin and eosin staining, $\times 200$ magnification

\section{Nonimmune cells in EALs and AALs}

Here, we quantified two resident cell types of the artery wall: VSMCs and ECs. We used a common marker of monocytic phagocytes-macrosialin $\left(\mathrm{CD} 68^{+}\right)$- to separate contractile VSMCs (CD45- ${ }^{-} \mathrm{SMA}^{+} \mathrm{CD} 68^{-}$cells) and intermediate macrophage-like VSMCs (CD45- $\alpha \mathrm{SMA}^{+} \mathrm{CD}^{+} 8^{+}$cells). ECs were identified as CD45- $\alpha \mathrm{SMA}^{-} \mathrm{CD} 31^{+}$cells (Fig. 1a).

The proportion of VSMCs among resident cells of the human coronary artery was $23.5(12.9 ; 33.4) \%$, and the proportion of ECs was $0.6(0.4 ; 2.0) \%$. Contractile VSMCs were the predominant subpopulation of common VSMCs: 90.61 (64.5; 96.2)\% in EALs and a slightly lower proportion in AALs [71 $(57.1 ; 90.5) \%, p=0.414]$. We did not find any differences in the proportion of either ECs or VSMCs between EALs and AALs (Table 2 and Fig. 2c-f).

Macrophage-like VSMCs were detectable in all samples of coronary atherosclerotic lesions, and the proportion of these cells was $1.9(0.8 ; 2.9) \%$ of all cells $[7.9(3.1 ; 33.2) \%$ in the total VSMC population] in EALs and $3.7(1.0 ; 9.1) \%$ of all cells [26.7 $(7.8 ; 41.3) \%$ of all VSMCs] in AAL samples (Table 2).

Even though the number of common VSMCs remained nearly constant from EALs to AALs, a slight shift in the ratios of contractile and macrophage-like subpopulations was observed. Although the proportion of contractile VSMCs tended to be lower in AALs than in EALs, the proportion of macrophage-like VSMCs tended to be higher, albeit statistically insignificantly ( $p=0.414$ for both comparisons). Additionally, the percentage of macrophage-like VSMCs positively correlated with the histological type of atherosclerotic lesions $(r=0.81, p=0.029 ; \rho=0.87, p=0.010$; Fig. $2 g, h)$.

\section{Inter- and intraindividual variation of cellular composition of EALs and AALs}

Accumulation of VSMCs and ECs was associated with an increased macrophage number in two patients (Patients \#2 and \#3; Fig. 2i), whereas the other patients did not show this elevation.

We had an opportunity to assess cellular composition in several advanced coronary atherosclerotic plaques (2 to 3 per patient) in four donors (Patients \# 1-4; Fig. 2i). AALs manifested high variation of cellular composition within the same artery sample. The highest variation of cell numbers was registered in terms of contractile VSMCs (7-fold on average) and in terms of total VSMCs, macrophages, and ECs (5-fold on average). The proportions of macrophage-like VSMCs were very similar among the plaques within each artery sample (each patient).

\section{A case of a coronary sirolimus-eluting stent implanted 10 months before death}

We investigated the case of in-stent restenosis that occurred 10 months after sirolimus-eluting coronary stenting. The restenosis was the cause of myocardial infarction (Table 1, case ID 4). Mechanisms of rapid neoatherosclerosis are unclear at present, partly due to the lack of information regarding cellular composition of stented arteries. Common mechanisms of restenosis include VSMC proliferation, endothelial dysfunction, and development of inflammation within a short period owing to vascular injury. ${ }^{34}$

We compared the stented coronary artery (including neointima and underlying media) with initial atherosclerotic alterations in the vicinity of the stented region. During the 
medRxiv preprint doi: https://doi.org/10.1101/2021.10.07.21264647; this version posted October $7,2021$. The copyright holder for this preprint (which was not certified by peer review) is the author/funder, who has granted medRxiv a license to display the preprint in perpetuity.

It is made available under a CC-BY 4.0 International license .

histological analysis of stented segment, we documented a specific sign of neoatherosclerosis: a cholesterol-rich necrotic core with hemorrhages, calcification, and a thin cap (Fig. 2j). Adjacent tissue featured intima thickening and differential proliferation of cell types (Fig. 2k).

Analysis of cell composition of the tissues adjacent to stented and nonstented arteries by flow cytometry did not show any differences (Table 3). By contrast, the total macrophage content and macrophage proportion among leukocytes were significantly higher (5.3- and 5.4-fold, respectively) in the stented artery than in nonstented AAL samples. In particular, leukocytes of the stented plaque contained almost $40 \%$ of macrophages, whereas in AALs, this proportion was almost $7 \%$ [6.89 $(5.0 ; 7.8) \%]$.

Furthermore, we noted significantly more macrophage-like VSMCs in the stented plaque $(9.9 \%)$ than in nonstented AALs [3.7 $(1 ; 9.1) \%]$. The relative number of macrophagelike VSMCs in the segment adjacent to the stent was also remarkably higher (18.9\%) than that in EALs $[1.9(0.8 ; 2.9) \%]$, without significance.

Finally, EC content of the stented plaque $(4.7 \%)$ was significantly higher in comparison with nonstented AALs [0.6 $(0.5 ; 2.8) \%, p=0.008$; Table 3].

Table 3. Cell numbers in atherosclerotic lesions in sirolimus-eluting stented and nonstented coronary arteries

\begin{tabular}{|c|c|c|c|c|c|c|}
\hline \multirow{2}{*}{ Cell types } & \multicolumn{2}{|c|}{ Nonstented arteries } & \multirow{2}{*}{$\begin{array}{l}\text { Segment } \\
\text { adjacent to } \\
\text { the stent }\end{array}$} & \multirow{2}{*}{$\begin{array}{l}\text { Sirolimus- } \\
\text { eluting } \\
\text { stented } \\
\text { artery }\end{array}$} & \multirow{2}{*}{$\begin{array}{l}P \text { value } \\
\text { EAL vs } \\
\text { segment } \\
\text { adjacent to } \\
\text { stent }\end{array}$} & \multirow{2}{*}{$\begin{array}{l}\text { P value } \\
\text { AAL vs } \\
\text { sirolimus- } \\
\text { eluting } \\
\text { stented } \\
\text { artery }\end{array}$} \\
\hline & $\operatorname{EAL}(n=5)$ & $\operatorname{AAL}(n=11)$ & & & & \\
\hline $\begin{array}{l}\text { Leukocytes } \\
\text { (\% of singlets) }\end{array}$ & $15.7(11.9 ; 16.1)$ & $8.1(3.9 ; 8.6)$ & 3.9 & 7.8 & 0.125 & 0.910 \\
\hline $\begin{array}{l}\text { Macrophages } \\
\text { (\% of singlets) }\end{array}$ & $0.39(0.28 ; 0.55)$ & $0.59(0.2 ; 0.66)$ & 1.1 & 3.7 & 0.125 & $0.004^{*}$ \\
\hline $\begin{array}{l}\text { Macrophages } \\
\text { (\% of leukocytes) }\end{array}$ & $3.04(1.9 ; 3.6)$ & $6.89(5.0 ; 7.8)$ & 28.2 & 37.4 & 0.125 & $0.004^{*}$ \\
\hline $\begin{array}{l}\text { VSMCs } \\
\text { (\% of singlets) }\end{array}$ & $17.6(10 ; 41.5)$ & $24(10 ; 35.5)$ & 34.5 & 29.9 & 0.250 & 0.250 \\
\hline $\begin{array}{l}\text { Contractile VSMCs } \\
\text { (\% of singlets) }\end{array}$ & $15.9(7.3 ; 39.7)$ & $15.7(7.2 ; 26.8)$ & 15.1 & 19.3 & 0.625 & 0.652 \\
\hline $\begin{array}{l}\text { Contractile VSMCs } \\
\text { (\% of all VSMCs) }\end{array}$ & $90.6(64.5 ; 96.2)$ & $71.0(57.1 ; 90.5)$ & 43.7 & 65.5 & 0.125 & 0.359 \\
\hline $\begin{array}{l}\text { Macrophage-like } \\
\text { VSMCs } \\
\text { (\% of singlets) }\end{array}$ & $1.9(0.8 ; 2.9)$ & $3.7(1 ; 9.1)$ & 18.9 & 9.9 & 0.125 & $0.020^{*}$ \\
\hline $\begin{array}{l}\text { Macrophage-like } \\
\text { VSMCs } \\
\text { (\% of all VSMCs) }\end{array}$ & $7.9(3.1 ; 33.2)$ & $26.7(7.8 ; 41.3)$ & 54.8 & 32.3 & 0.125 & 0.359 \\
\hline ECs (\% of singlets) & $0.4(0.3 ; 1.4)$ & $0.6(0.5 ; 2.8)$ & 1.1 & 4.7 & 0.250 & $0.008^{*}$ \\
\hline
\end{tabular}

AAL, advanced atherosclerotic lesion; EAL, early atherosclerotic lesion; ECs: endothelial cells; VSMCs, vascular smooth muscle cells, *statistically significant.

\section{DISCUSSION}

The atherosclerotic plaque is a complex structure composed of at least seven main cell types of various phenotypes and an extracellular matrix and involves cell-cell interactions. It is well known that immune cells play an important role in atherosclerosis.

At first, we compared the numbers of leukocytes $\left(\mathrm{CD} 45^{+}\right)$and macrophages $\left(\mathrm{CD} 45^{+} \mathrm{CD} 68^{+}\right)$between early and advanced human coronary atherosclerotic lesions by flow cytometry. There was a significantly lower relative number of $C D 45^{+}$cells in AALs $(8.1 \%)$ than in EALs (15.7\%).

The depletion of lesional CD45 cells can be driven by cell death, egress, and limited cell recruitment. A study on leukocyte dynamics during atherogenesis in $\mathrm{ApoE}^{-/-}$mice has revealed increased cell death in carotid plaques, corresponding to decreased CD45 staining. ${ }^{35}$ The current theory of progressive atherogenesis includes secondary necrosis, 
medRxiv preprint doi: https://doi.org/10.1101/2021.10.07.21264647; this version posted October 7, 2021. The copyright holder for this preprint (which was not certified by peer review) is the author/funder, who has granted medRxiv a license to display the preprint in perpetuity.

It is made available under a CC-BY 4.0 International license .

which occurs after lipid loading of macrophages and a loss of their ability to utilize lipids. ${ }^{36}$ Our knowledge about the death of T and B cells, DCs, and other leukocyte subpopulations is much more limited as compared to macrophages. ${ }^{37}$

Another type of cell death is apoptosis, which performs an ambiguous function in atherogenesis, depending on the cell type and stage. ${ }^{38}$ In early studies on human atherosclerosis, plenty of apoptotic immune cells turned out to be located in the shoulders and necrotic core of the plaque. ${ }^{39}$ Macrophage apoptosis promotes the regression of early atherosclerotic lesions but also contributes to necrotic-core enlargement and vulnerability of the advanced atherosclerotic plaque. ${ }^{40}$

In our study, cell egress from plaques cannot be ruled out as a potential mechanism of $\mathrm{CD} 45^{+}$cell loss in the atherosclerotic lesion. Reduced leukocyte influx and the enhanced egress initiate inflammation resolution. Macrophages, especially resident macrophages, rather poorly emigrate from tissues. Among them, DCs are best known for clearing from organs by emigrating to draining lymph nodes upon activation. ${ }^{41}$ On the contrary, it has been demonstrated that reverse transendothelial migration of neutrophils is promoted by macrophage interaction via redox-regulated Src family kinase signaling in response to reactive oxygen species. ${ }^{42}$ Leukocyte egress can have a beneficial effect on atherosclerosis resolution but reversely migrating neutrophils can promote systemic inflammation and tissue damage. ${ }^{43}$

In our study, $\mathrm{CD} 45^{+} \mathrm{CD} 68^{+}$cell relative numbers among all cells remained unchanged from EALs to AALs (0.39-0.59\% of all cells and 3-7\% of leukocytes), but the proportion of these cells among leukocytes was significantly higher in the advanced lesions (7\%) than in early ones (3\%, Fig. 3a). We propose that the immune cell disproportion in atherosclerotic plaques predominantly occurred because of non-CD68+ leukocytes, probably, T lymphocytes (as the largest leukocyte population in human $\mathrm{AALs}^{27}$ ) or other cells.

Studies on the immune-cell subsets and cellular composition of aortic atherosclerotic lesions in mouse models and human carotid and coronary arteries by cytometry or cellsorting methods (flow cytometry, CyTOF, and scRNA-seq) have yielded discrepant results due to differences in study design, methodological approaches, and biomaterial sources $^{11,16,17,23-28,35,44-46}$ (Fig. 3a and b). There are mostly macrophages and myeloid cells (14-69\%) plus some T cells (8-49\%) and B cells (6-27\%) among leukocytes in murine aortic atherosclerotic lesions; these variations are a consequence of substantial differences among mouse strains, in tissue digestion and cell isolation protocols, and in leukocyte marker panels used in different studies ${ }^{17,44,45}$ (Fig. 3a). In our study, human early and advanced coronary lesions contained 3-7\% of macrophages in the leukocyte population (Fig. 3a). These results contradict previously published percentages of macrophages and myeloid cells in carotid advanced atherosclerotic plaques (15-20\% ${ }^{25,26}$; Fig. 3a). Different arteries, cell isolation protocols, leukocyte markers, and methods were employed by us and other authors, ${ }^{25,26,29}$ making a direct comparison between the studies challenging.

Unfortunately, most research articles on human atherosclerotic lesions represent single-time point analyses, mainly of advanced stages (Fig. 3a and b). Nonetheless, the examination of carotid arteries by Alsaigh T. et al. (2020) ${ }^{24}$ revealed increased percentages of myeloid cells among all cells in a carotid atherosclerotic plaque $(26 \%)$ in comparison to a proximal adjacent tissue (11\%). This pathological upregulation of myeloid cells in carotid arteries is consistent with our findings about the progression from EALs to AALs in coronary arteries (3\% to $7 \%$ of myeloid cells in the leukocyte population; Fig. $3 a$ ).

Additionally, the most common specimens for studying human atherosclerosis are carotid endarterectomy samples, which contain intima with a plaque and little media. It should be noted that in our study, T cells and myeloid cells were the main subpopulations of leukocytes, at 59-69\% and 15-20\%, and of all cells in carotid plaques, at 7-52\% and 11$26 \%$, respectively (Fig. 3a and b). The proportion of B cells was $3-4 \%$ among leukocytes in carotid atherosclerotic plaques (Fig. 3a). Moreover, VSMCs made up 5-57\% of all cells in carotid plaques (Fig. 3b).

In this study, we analyzed whole coronary arteries, which are different from carotid arteries in their morphology and temporal and spatial cellular patterns ${ }^{47}$ Compared with 
medRxiv preprint doi: https://doi.org/10.1101/2021.10.07.21264647; this version posted October 7, 2021. The copyright holder for this preprint (which was not certified by peer review) is the author/funder, who has granted medRxiv a license to display the preprint in perpetuity.

It is made available under a CC-BY 4.0 International license.

carotid plaques, the coronary arteries of patients with atherosclerosis turned out to be enriched in VSMCs, which in this tissue constitute $16-35 \%$ and $40 \%$ of all cells according to our data and other studies, ${ }^{11}$ respectively (Fig. 3b). The proportions of $\mathrm{T}$, B, and myeloid cells were nearly equal in coronary arteries (approximately $10 \%$ for each cell type). ${ }^{46}$

Media and adventitia of atherosclerotic plaques contain most of VSMCs and B cells; therefore, in a carotid lesion that lacks these tissues, counts of some leukocytes are overestimated in comparison with a whole artery. Winkels et al. (2018) found predominant accumulation of myeloid cells and T cells in microdissected mouse aortic plaques and human carotid plaques while B cells predominated in the adventitia and proved to be only a minor subpopulation in plaques. ${ }^{44}$ In the present work, we isolated cells from whole coronary arteries encompassing intima, media, and adventitia; hence, we registered higher prevalence of VSMCs and a smaller proportion of macrophages as compared with carotid arteries.

Disproportionate amounts of immune cells in arteries depend on the vascular bed. ${ }^{48}$ Here, we identified differences in leukocyte composition and in the proportion of macrophages not only between EALs and AALs but also among different individuals and among AALs in some patients.

It is reported that contractile $\alpha \mathrm{SMA}^{+}$cells can gain a capacity for lipid loading via socalled transdifferentiation. ${ }^{36}$ During the phenotypic switching, they acquire macrophage-like properties, including CD68 expression, as confirmed in a murine atherosclerosis model. ${ }^{49}$ Coexpression of $\alpha$ SMA (also known as ACTA2) and CD68 in smooth muscle cells is observed in lineage-tracking murine models, whereas $16 \%$ of $\mathrm{CD}^{+} 8^{+}$cells may have nonmyeloid origin. ${ }^{50}$

In human advanced coronary plaques, Allahverdian and coworkers (2014) detected costaining of $\alpha$ SMA and lipids (oil red O staining) in $50 \% \pm 7 \%$ of all foam cells. Furthermore, they noticed that $40 \% \pm 6 \%$ of all $\mathrm{CD}^{+} 8^{+}$cells also expressed $\alpha \mathrm{SMA} .{ }^{13}$ On the other hand, this number may include both myeloid and VSMC origin cells owing to a lack of CD45 staining.

In this work, we revealed that the relative number of $\mathrm{CD}^{2}{ }^{-} \alpha \mathrm{SMA}^{+} \mathrm{CD} 68^{+}$cells was $2-$ $4 \%$ and $8-27 \%$ of all $\alpha \mathrm{SMA}^{+}$cells in early and late coronary atherosclerotic lesions, respectively, demonstrating that this cell phenotype is present at early stages of human coronary lesions. Moreover, the number of macrophage-like VSMCs significantly correlated with the number of $\mathrm{CD}_{4} 5^{+} \mathrm{CD} 68^{+}$macrophages $(r=0.81 ; \rho=0.64 ; p<0.05)$ and the histological type of an atherosclerotic lesion $(r=0.81 ; \rho=0.87 ; p<0.05)$. These results are in agreement with the existing knowledge about macrophage-VSMC interactions and cell phenotypic switching. ${ }^{51}$ In another study, cocultivation of VSMCs and macrophages revealed a proinflammatory influence of the latter, stimulation of VSMC proliferation, and acquisition of a procalcific phenotype by VSMCs. ${ }^{52}$ Nonetheless, the specific stimuli causing VSMCs to acquire the macrophage-like phenotype remain unclear.

We demonstrated notable differences in the numbers of some cell types between nonstented and sirolimus-eluting stented segments of human coronary atherosclerotic plaques, especially in the proportion of ECs ( $0.6 \%$ vs $4.7 \%$ of singlets $)$, macrophages $(0.59 \%$ vs $3.7 \%$ of singlets and $6.89 \%$ vs. $37.4 \%$ of leukocytes), and macrophage-like VSMCs $(3.7 \%$ vs. $9.9 \%$ of all cells), while the proportions of contractile VSMCs were similar (Table 3 and Fig. 3). Additionally, we did not find statistically significant differences in cellular composition between early plaques and the arterial tissue adjacent to the stent. 
medRxiv preprint doi: https://doi.org/10.1101/2021.10.07.21264647; this version posted October 7, 2021. The copyright holder for this preprint (which was not certified by peer review) is the author/funder, who has granted medRxiv a license to display the preprint in perpetuity.
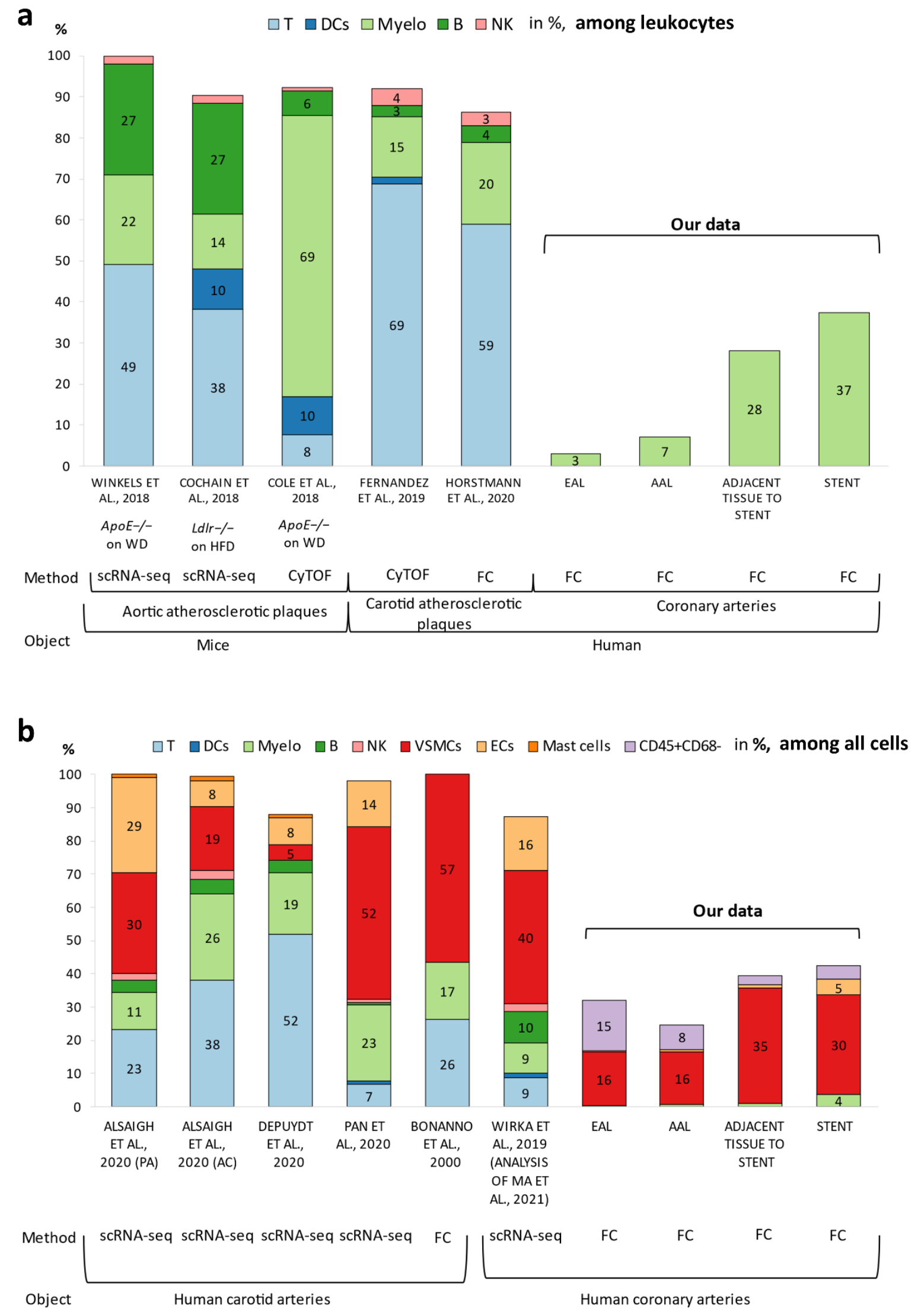

Figure 3. a. Immune-cell composition of murine aortic $\mathrm{c}^{17,44,45}$ and human ${ }^{25,26}$ atherosclerotic lesions. b. Cellular composition of human carotid ${ }^{23,24,27,28}$ and coronary atherosclerotic lesions ${ }^{11,46}$. Alsaigh et al. studied a proximal tissue adjacent to a plaque (PA) and a carotid atherosclerotic plaque (AC). EAL: early atherosclerotic lesion, AAL: advanced atherosclerotic lesion. FC: flow cytometry, CyTOF: mass cytometry, scRNA-seq: single-cell RNA sequencing; T: T cells, DCs: dendritic cells, Myelo: myeloid cells, B: B cells, NK: natural killers, WD: Western diet, and HFD: high-fat diet. 
medRxiv preprint doi: https://doi.org/10.1101/2021.10.07.21264647; this version posted October 7, 2021. The copyright holder for this preprint (which was not certified by peer review) is the author/funder, who has granted medRxiv a license to display the preprint in

perpetuity.
It is made available under a CC-BY 4.0 International license .

Our results are consistent with data from human autopsy studies on drug-eluting stents in coronary arteries. Restenotic samples offer evidence of hypercellularity or ongoing cellular proliferation..$^{53,54}$ It is reported that the main driver of in-stent restenosis is VSMC dedifferentiation and proliferation accompanying macrophage infiltration and neointimal angiogenesis. ${ }^{55}$ By contrast, Schwartz et al. (1996) hypothesized that restenotic arteries are characterized by cellular proliferation only at early stages; consequently, lesions derived from human coronary arteries are not characterized by cellular proliferation if sampled at later stages. ${ }^{56}$ Therefore, further studies with larger sample size are needed to test this hypothesis.

One of the limitations of this study is small sample size. Nonetheless, some of our results are statistically significant even with 16 specimens of coronary artery plaques. Additionally, the enzymatic tissue digestion for the isolation of cells from an atherosclerotic lesion may induce cell death or other enzymatic-extraction-related artifacts that may affect flow-cytometric results in a batch-dependent manner. Besides, the cellular composition of coronary arteries in this work was not verified by other methods.

Although all the analyzed patients were clinically symptomatic (had acute coronary syndrome), AALs in this study were stable according to histological analysis, except for two samples in one case of restenotic coronary lesions. To confirm the significance and generality of our findings, further research would be warranted with larger numbers of atherosclerotic lesions that differ in histological vulnerability and vascular beds among patients' subgroups (e.g., clinically symptomatic/asymptomatic and diabetic/nondiabetic).

Here, we for the first time investigated ECs (CD45 $\left.{ }^{-} \alpha \mathrm{SMA}^{-} \mathrm{CD} 31^{+}\right)$, leukocytes $\left(\mathrm{CD} 45^{+}\right)$ and separately macrophages $\left(\mathrm{CD} 45^{+} \mathrm{CD} 68^{+}\right)$and contractile $\left(\mathrm{CD} 45^{-} \alpha \mathrm{SMA}^{+} \mathrm{CD} 68^{-}\right)$and macrophage-like $\left(\mathrm{CD}^{2} 5^{-} \alpha \mathrm{SMA}^{+} \mathrm{CD} 68^{+}\right)$VSMCs in EALs and AALs of human coronary arteries by flow cytometry. We documented differences in CD45+ leukocyte and CD45+CD68 ${ }^{+}$ macrophage numbers between EALs and AALs. The proportion of CD45+ leukocytes diminished, while the subpopulation of $\mathrm{CD} 45^{+} \mathrm{CD} 68^{+}$macrophages expanded in advanced coronary atherosclerotic plaques compared with the early lesions. We detected $\alpha S M A^{+} C D 68^{+}$VSMCs in EALs. There was also a strong positive correlation of the $\alpha S M{ }^{+}{ }^{+} D 68^{+}$VSMC number with the $\mathrm{CD} 45^{+}{ }^{+} D 68^{+}$macrophage number and with the histological type of atherosclerotic lesions. The restenotic coronary lesion was found to contain large numbers of ECs, macrophages, and $\alpha S M A^{+} C D 68^{+}$VSMCs. In conclusion, we would like to emphasize the pivotal role of complex changes in the numbers of adaptiveimmunity cells and macrophage-like VSMCs during human coronary atherosclerosis.

\section{Acknowledgments}

The authors thank a pathologist of Siberian State Medical University, Nadezhda Krahmal, for her help with the biomaterial collection. The English language was corrected and certified by shevchuk-editing.com.

\section{Sources of funding}

RSC \#17-75-10146: biomaterial collection and storage, tissue disaggregation

RFBR \#20-315-90076: flow cytometry and statistical analysis

\section{Disclosures}

None. 
medRxiv preprint doi: https://doi.org/10.1101/2021.10.07.21264647; this version posted October 7, 2021. The copyright holder for this preprint (which was not certified by peer review) is the author/funder, who has granted medRxiv a license to display the preprint in

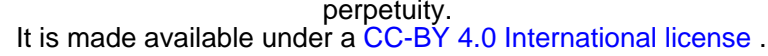

\section{References}

1. Libby P, Buring JE, Badimon L, et al. Atherosclerosis. Nature Reviews Disease Primers. 2019;5(1):1-18. doi:10.1038/s41572-019-0106-z

2. Stary HC, Chandler AB, Dinsmore RE, et al. A definition of advanced types of atherosclerotic lesions and a histological classification of atherosclerosis. A report from the Committee on Vascular Lesions of the Council on Arteriosclerosis, American Heart Association. Circulation. 1995;92(5):1355-1374.

3. Virmani R, Burke AP, Kolodgie FD, Farb A. Vulnerable plaque: the pathology of unstable coronary lesions. J Interv Cardiol. 2002;15(6):439-446.

4. Virmani R, Burke AP, Farb A, Kolodgie FD. Pathology of the Vulnerable Plaque. Journal of the American College of Cardiology. 2006;47(8, Supplement):C13-C18. doi:10.1016/j.jacc.2005.10.065

5. Wang D, Wang Z, Zhang L, Wang Y. Roles of Cells from the Arterial Vessel Wall in Atherosclerosis. Mediators of Inflammation. doi:10.1155/2017/8135934

6. Davies PF, Civelek M, Fang Y, Fleming I. The atherosusceptible endothelium: endothelial phenotypes in complex haemodynamic shear stress regions in vivo. Cardiovasc Res. 2013;99(2):315-327. doi:10.1093/cvr/cvt101

7. Dobnikar L, Taylor AL, Chappell J, et al. Disease-relevant transcriptional signatures identified in individual smooth muscle cells from healthy mouse vessels. Nat Commun. 2018;9(1):4567. doi:10.1038/s41467-018-06891-x

8. Galkina E, Ley K. Immune and Inflammatory Mechanisms of Atherosclerosis. Annu Rev Immunol. 2009;27:165-197. doi:10.1146/annurev.immunol.021908.132620

9. Miller $\mathrm{Yl}$, Choi S-H, Wiesner $\mathrm{P}$, et al. Oxidation-specific epitopes are danger-associated molecular patterns recognized by pattern recognition receptors of innate immunity. Circ Res. 2011;108(2):235-248. doi:10.1161/CIRCRESAHA.110.223875

10. Cushing SD, Berliner JA, Valente AJ, et al. Minimally modified low density lipoprotein induces monocyte chemotactic protein 1 in human endothelial cells and smooth muscle cells. PNAS. 1990;87(13):5134-5138.

11. Wirka RC, Wagh D, Paik DT, et al. Atheroprotective roles of smooth muscle cell phenotypic modulation and the TCF21 disease gene as revealed by single-cell analysis. Nat Med. 2019;25(8):1280-1289. doi:10.1038/s41591-019-0512-5

12. Iwata H, Aikawa M. Dynamic Interplay Between Smooth Muscle Cells and Macrophages in Vascular Disease. Muscle Cell and Tissue. Published online September 2, 2015. doi:10.5772/61089

13. Allahverdian Sima, Chehroudi Ali Cyrus, McManus Bruce M., Abraham Thomas, Francis Gordon A. Contribution of Intimal Smooth Muscle Cells to Cholesterol Accumulation and Macrophage-Like Cells in Human Atherosclerosis. Circulation. 2014;129(15):1551-1559. doi:10.1161/CIRCULATIONAHA.113.005015

14. Durham AL, Speer MY, Scatena M, Giachelli CM, Shanahan CM. Role of smooth muscle cells in vascular calcification: implications in atherosclerosis and arterial stiffness. Cardiovasc Res. 2018;114(4):590-600. doi:10.1093/cvr/cvy010

15. Gomez D, Owens GK. Smooth muscle cell phenotypic switching in atherosclerosis. Cardiovascular Research. 2012;95(2):156-164. doi:10.1093/cvr/cvs115

16. Galkina E, Kadl A, Sanders J, Varughese D, Sarembock IJ, Ley K. Lymphocyte recruitment into the aortic wall before and during development of atherosclerosis is partially L-selectin dependent. Journal of Experimental Medicine. 2006;203(5):1273-1282. doi:10.1084/jem.20052205

17. Cole JE, Park I, Ahern DJ, et al. Immune cell census in murine atherosclerosis: cytometry by time of flight illuminates vascular myeloid cell diversity. Cardiovasc Res. 2018;114(10):13601371. doi:10.1093/cvr/cvy109 
medRxiv preprint doi: https://doi.org/10.1101/2021.10.07.21264647; this version posted October 7, 2021. The copyright holder for this preprint (which was not certified by peer review) is the author/funder, who has granted medRxiv a license to display the preprint in

perpetuity.
It is made available under a CC-BY 4.0 International license .

18. Lebedeva A, Vorobyeva $D$, Vagida $M$, et al. Ex vivo culture of human atherosclerotic plaques: A model to study immune cells in atherogenesis. Atherosclerosis. 2017;267:90-98. doi:10.1016/j.atherosclerosis.2017.10.003

19. Novikova OA, Nazarkina ZK, Cherepanova AV, et al. Isolation, culturing and gene expression profiling of inner mass cells from stable and vulnerable carotid atherosclerotic plaques. PLoS One. 2019;14(6). doi:10.1371/journal.pone.0218892

20. Emini Veseli B, Perrotta P, De Meyer GRA, et al. Animal models of atherosclerosis. European Journal of Pharmacology. 2017;816:3-13. doi:10.1016/j.ejphar.2017.05.010

21. Golforoush P, Yellon DM, Davidson SM. Mouse models of atherosclerosis and their suitability for the study of myocardial infarction. Basic Res Cardiol. 2020;115(6):73. doi:10.1007/s00395-020-00829-5

22. van Dijk RA, Duinisveld AJF, Schaapherder AF, et al. A Change in Inflammatory Footprint Precedes Plaque Instability: A Systematic Evaluation of Cellular Aspects of the Adaptive Immune Response in Human Atherosclerosis. J Am Heart Assoc. 2015;4(4).

doi:10.1161/JAHA.114.001403

23. Pan H, Xue C, Auerbach BJ, et al. Single-Cell Genomics Reveals a Novel Cell State During Smooth Muscle Cell Phenotypic Switching and Potential Therapeutic Targets for Atherosclerosis in Mouse and Human. Circulation. Published online September 23, 2020. doi:10.1161/CIRCULATIONAHA.120.048378

24. Alsaigh T, Evans D, Frankel D, Torkamani A. Decoding the transcriptome of atherosclerotic plaque at single-cell resolution. bioRxiv. Published online March 4, 2020:2020.03.03.968123. doi:10.1101/2020.03.03.968123

25. Fernandez DM, Rahman AH, Fernandez NF, et al. Single-cell immune landscape of human atherosclerotic plaques. Nature Medicine. 2019;25(10):1576-1588. doi:10.1038/s41591-0190590-4

26. Horstmann $\mathrm{H}$, Lindau A, Hansen $\mathrm{S}$, et al. Atlas of the immune cell repertoire in human atherosclerotic plaques characterized by single cell RNA-sequencing and multi-color flow cytometry. European Heart Journal. 2020;41(ehaa946.2353).

doi:10.1093/ehjci/ehaa946.2353

27. Depuydt Marie AC, Prange Koen HM, Slenders Lotte, et al. Microanatomy of the Human Atherosclerotic Plaque by Single-Cell Transcriptomics. Circulation Research. 0(0). doi:10.1161/CIRCRESAHA.120.316770

28. Bonanno E, Mauriello A, Partenzi A, Anemona L, Spagnoli LG. Flow cytometry analysis of atherosclerotic plaque cells from human carotids: a validation study. Cytometry. 2000;39(2):158-165. doi:10.1002/(SICI)1097-0320(20000201)39:2<158::AID-CYTO9>3.0.CO;28

29. Sternberg Z, Ghanim H, Gillotti KM, et al. Flow cytometry and gene expression profiling of immune cells of the carotid plaque and peripheral blood. Atherosclerosis. 2013;229(2):338347. doi:10.1016/j.atherosclerosis.2013.04.035

30. Grivel J-C, Ivanova O, Pinegina N, et al. ACTIVATION OF T LYMPHOCYTES IN ATHEROSCLEROTIC PLAQUES. Arterioscler Thromb Vasc Biol. 2011;31(12):2929-2937. doi:10.1161/ATVBAHA.111.237081

31. Van Brussel I, Ammi R, Rombouts M, et al. Fluorescent activated cell sorting: An effective approach to study dendritic cell subsets in human atherosclerotic plaques. Journal of Immunological Methods. 2015;417:76-85. doi:10.1016/j.jim.2014.12.010

32. Kritikou E, Depuydt MAC, de Vries MR, et al. Flow Cytometry-Based Characterization of Mast Cells in Human Atherosclerosis. Cells. 2019;8(4). doi:10.3390/cells8040334

33. Bonaccorsi I, Spinelli D, Cantoni C, et al. Symptomatic Carotid Atherosclerotic Plaques Are Associated With Increased Infiltration of Natural Killer (NK) Cells and Higher Serum Levels of NK Activating Receptor Ligands. Front Immunol. 2019;10. doi:10.3389/fimmu.2019.01503

34. Grewe PH, Deneke T, Machraoui A, Barmeyer J, Müller K-M. Acute and chronic tissue response to coronary stent implantation: pathologic findings in human specimen. Journal of 
medRxiv preprint doi: https://doi.org/10.1101/2021.10.07.21264647; this version posted October 7, 2021. The copyright holder for this preprint (which was not certified by peer review) is the author/funder, who has granted medRxiv a license to display the preprint in perpetuity.

It is made available under a CC-BY 4.0 International license.

the American College of Cardiology. 2000;35(1):157-163. doi:10.1016/S0735-1097(99)00486-

6

35. Alberts-Grill N, Rezvan A, Son DJ, et al. Dynamic immune cell accumulation during flowinduced atherogenesis in mouse carotid artery: An expanded flow cytometry method. Arterioscler Thromb Vasc Biol. 2012;32(3):623-632. doi:10.1161/ATVBAHA.111.242180

36. Basatemur GL, Jørgensen HF, Clarke MCH, Bennett MR, Mallat Z. Vascular smooth muscle cells in atherosclerosis. Nature Reviews Cardiology. 2019;16(12):727-744. doi:10.1038/s41569-019-0227-9

37. Mallat Z, Tedgui A. Apoptosis in the vasculature: mechanisms and functional importance. British Journal of Pharmacology. 2000;130(5):947-962. doi:10.1038/sj.bjp.0703407

38. Rayner Katey J. Cell Death in the Vessel Wall. Arteriosclerosis, Thrombosis, and Vascular Biology. 2017;37(7):e75-e81. doi:10.1161/ATVBAHA.117.309229

39. Björkerud S, Björkerud B. Apoptosis is abundant in human atherosclerotic lesions, especially in inflammatory cells (macrophages and T cells), and may contribute to the accumulation of gruel and plaque instability. Am J Pathol. 1996;149(2):367-380.

40. Seimon T, Tabas I. Mechanisms and consequences of macrophage apoptosis in atherosclerosis. J Lipid Res. 2009;50(Suppl):S382-S387. doi:10.1194/jIr.R800032-JLR200

41. Randolph GJ. Mechanisms that regulate macrophage burden in atherosclerosis. Circ Res. 2014;114(11):1757-1771. doi:10.1161/CIRCRESAHA.114.301174

42. Wang J, Hossain M, Thanabalasuriar A, Gunzer M, Meininger C, Kubes P. Visualizing the function and fate of neutrophils in sterile injury and repair. Science. 2017;358(6359):111-116. doi:10.1126/science.aam9690

43. Schumski A, Winter C, Döring Y, Soehnlein O. The Ins and Outs of Myeloid Cells in Atherosclerosis. JIN. 2018;10(5-6):479-486. doi:10.1159/000488091

44. Winkels Holger, Ehinger Erik, Vassallo Melanie, et al. Atlas of the Immune Cell Repertoire in Mouse Atherosclerosis Defined by Single-Cell RNA-Sequencing and Mass Cytometry. Circulation Research. 2018;122(12):1675-1688. doi:10.1161/CIRCRESAHA.117.312513

45. Cochain Clément, Vafadarnejad Ehsan, Arampatzi Panagiota, et al. Single-Cell RNA-Seq Reveals the Transcriptional Landscape and Heterogeneity of Aortic Macrophages in Murine Atherosclerosis. Circulation Research. 2018;122(12):1661-1674. doi:10.1161/CIRCRESAHA.117.312509

46. Ma WF, Hodonsky CJ, Turner AW, et al. Single-cell RNA-seq analysis of human coronary arteries using an enhanced workflow reveals SMC transitions and candidate drug targets. bioRxiv. Published online March 17, 2021:2020.10.27.357715.

doi:10.1101/2020.10.27.357715

47. Sigala F, Oikonomou E, Antonopoulos AS, Galyfos G, Tousoulis D. Coronary versus carotid artery plaques. Similarities and differences regarding biomarkers morphology and prognosis. Current Opinion in Pharmacology. 2018;39:9-18. doi:10.1016/j.coph.2017.11.010

48. Biessen EAL, Sluimer JC. Staging Lymphocyte Presence in Human Atherosclerosis: A Tale Told by Numbers. J Am Heart Assoc. 2015;4(4). doi:10.1161/JAHA.115.001909

49. Rong JX, Shapiro M, Trogan E, Fisher EA. Transdifferentiation of mouse aortic smooth muscle cells to a macrophage-like state after cholesterol loading. Proc Natl Acad Sci U S A. 2003;100(23):13531-13536. doi:10.1073/pnas.1735526100

50. Albarrán-Juárez J, Kaur H, Grimm M, Offermanns S, Wettschureck N. Lineage tracing of cells involved in atherosclerosis. Atherosclerosis. 2016;251:445-453.

doi:10.1016/j.atherosclerosis.2016.06.012

51. Ramel D, Gayral S, Sarthou M-K, Augé N, Nègre-Salvayre A, Laffargue M. Immune and Smooth Muscle Cells Interactions in Atherosclerosis: How to Target a Breaking Bad Dialogue? Front Pharmacol. 2019;10. doi:10.3389/fphar.2019.01276

52. Zuniga MC, White SLP, Zhou W. Design and utilization of macrophage and vascular smooth muscle cell co-culture systems in atherosclerotic cardiovascular disease investigation. Vasc Med. 2014;19(5):394-406. doi:10.1177/1358863X14550542 
medRxiv preprint doi: https://doi.org/10.1101/2021.10.07.21264647; this version posted October 7, 2021. The copyright holder for this preprint (which was not certified by peer review) is the author/funder, who has granted medRxiv a license to display the preprint in It is made available under a CC-BY 4.0 International license.

53. Pickering JG, Weir L, Jekanowski J, Kearney MA, Isner JM. Proliferative activity in peripheral and coronary atherosclerotic plaque among patients undergoing percutaneous revascularization. J Clin Invest. 1993;91(4):1469-1480. doi:10.1172/JCI116352

54. Komatsu Ryushi, Ueda Makiko, Naruko Takahiko, Kojima Akiko, Becker Anton E. Neointimal Tissue Response at Sites of Coronary Stenting in Humans. Circulation. 1998;98(3):224-233. doi:10.1161/01.CIR.98.3.224

55. Zhang M, Cresswell N, Tavora F, Mont E, Zhao Z, Burke A. In-stent restenosis is associated with neointimal angiogenesis and macrophage infiltrates. Pathol Res Pract. 2014;210(12):1026-1030. doi:10.1016/j.prp.2014.04.004

56. Schwartz RS, Chu A, Edwards WD, et al. A proliferation analysis of arterial neointimal hyperplasia: lessons for antiproliferative restenosis therapies. International Journal of Cardiology. 1996;53(1):71-80. doi:10.1016/0167-5273(95)02499-9 